\title{
Sarcomatoid Chromophobe Renal Cell Carcinoma with Osteosarcoma-Like Differentiation which Presented as a Retroperitoneal Mass: A Case Report
}

\author{
Retroperitoneal Kitle Olarak Saptanan Osteosarkomatöz Farklılaşma \\ Gösteren Sarkomatoid Kromofob Renal Hücreli Karsinom: Olgu Sunumu
}

\author{
Ayşegül SARI', Gözde EVCiM' ${ }^{1}$ Murat ERMETE' , Serhat GÜR ${ }^{2}$ \\ Departments of ${ }^{1}$ Pathology and ${ }^{2} 1$ st Surgery, M.H. Izmir Atatürk Education and Research Hospital, IZMIR, TURKEY
}

\section{ABSTRACT}

Sarcomatoid component can occur in all histological subtypes of renal cell carcinoma but most commonly accompanies chromophobe renal cell carcinoma. The majority of the sarcomatoid components consist of malignant fibrous histiocytoma, fibrosarcoma or undifferentiated sarcoma areas. Heterologous differentiation in the form of osteosarcoma or rhabdomyosarcoma is very rarely encountered. We report a very rare case of a chromophobe renal cell carcinoma with osteosarcomatous differentiation that presented as a retroperitoneal mass. Renal cell carcinoma with sarcomatoid change should be always kept in mind when a retroperitoneal mass with sarcomatoid differentiation is encountered.

Key Words: Sarcomatoid renal cell carcinoma, Chromophobe renal cell carcinoma, Retroperitoneal neoplasms

\section{ÖZ}

Sarkomatöz komponent renal hücreli karsinomun tüm histolojik subtiplerinde görülebilirse de en sık kromofob renal hücreli karsinoma eşlik etmektedir. Sarkomatöz komponent sıklıkla malign fibröz histiositom, fibrosarkom ve indiferansiye sarkom alanlarından oluşmaktadır. Çok nadiren osteosarkom ya da rabdomiyosarkom formunda heterolog farklılaşma izlenir. Bu makalede, retroperitoneal kitle olarak saptanan ve osteosarkomatöz farklılaşma gösteren kromofob renal hücreli karsinom tanısı alan olgumuzu hem çok nadir görülmesi hem de retroperitoneal yerleşimli sarkomatoid özellikteki tümörlerde, sarkomatoid farklılaşma gösteren renal hücreli karsinomun ayırıcı tanıda akılda tutulması gerektiğini vurgulamak amaciyla sunduk.

Anahtar Sözcükler: Sarkomatoid renal hücreli karsinom, Kromofob renal hücreli karsinom, Retroperitoneal neoplaziler

\section{INTRODUCTION}

Chromophobe renal cell carcinomas (CRCC) are a rare renal cell carcinoma (RCC) variant that make up approximately $6 \%$ of all RCC cases (1). CRCC have a better prognosis than other RCC subtypes in general $(1,2)$. Sarcomatoid differentiation of CRCC generally indicates a worse prognosis as with all RCC cases (3-7). Sarcomatoid component is found in approximately $8 \%$ of all CRCC cases $(2,3)$. The sarcoma component of RCC generally consists of sarcoma areas such as malignant fibrous histiocytoma or fibrosarcoma (8). There may very rarely be heterologous differentiation in the form of osteosarcoma or rhabdomyosarcoma. There have been fewer than 10 case reports of a sarcomatoid RCC case containing heterologous elements in the sarcoma areas (7).

Received : 12.04 .2010

Accepted : 24.08.2010
We present a case with a retroperitoneal mass that was first thought to be a malignant mesenchymal tumor on intraoperative frozen section but was then diagnosed as sarcomatoid CRCC with osteosarcomatous differentiation on paraffin sections.

\section{CASE REPORT}

A 49-year-old patient presented at an outside instution with abdominal pain for 2 months. Magnetic resonance (MR) images showed a solid mass of $25 \times 20 \mathrm{~cm}$ in size that extended from the level of the left renal hilus to the iliac wing origin with a regular outer contour and necrosis foci (Figure 1). She was referred to our hospital for treatment.

Personal and family history revealed nothing of significance and laboratory values were also within normal limits. A

Correspondence: Ayşegül SARI

Department of Pathology, M.H. İmir Atatürk Education and Research

Hospital, Yeşilyurt, İZMİR, TURKEY

E-mail: aysegulakder@gmail.com Phone: +90 2322444444 


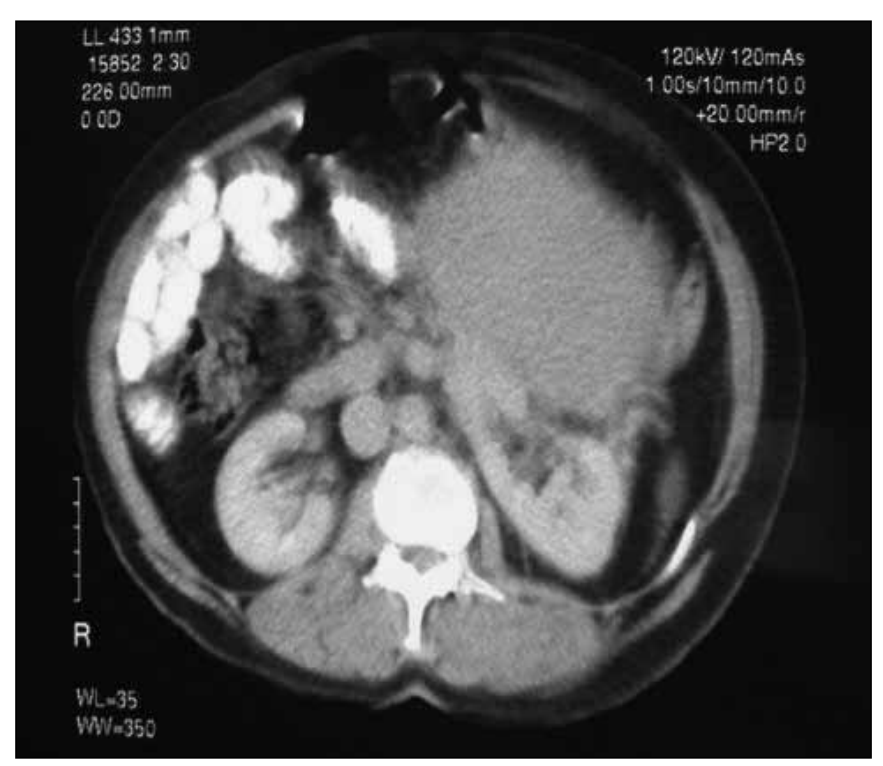

Figure 1: Upper abdominal MR reveals a solid mass lesion extending from the level of the left renal hilus to the origin of the iliac wing, $25 \times 20 \mathrm{~cm}$ in size with regular outer contours and containing necrotic areas.

tissue $1.5 \times 1 \times 0.5 \mathrm{~cm}$ in size obtained from the intraabdominal mass before the surgical excision showed atypical spindlelike cells making up long fascicules (Figure 2). The mass was reported as 'Malignant; consistent with mesenchymal tumor' and resected. Macroscopically, the mass was $18 \times 18 \times 11 \mathrm{~cm}$ in size and sections showed a solid dirty yellow tumor with widespread necrotic areas. A separate solid gray, bonedensity area $6 \mathrm{~cm}$ in diameter at the external surface of the tumor was noted (Figure 3). Microscopic evaluation of the tumor revealed typical CRCC areas consisting of polygonal cells containing centrally-located round hyperchromatic nuclei and pale, granular, eosinophilic cytoplasm and faint cytoplasmic margins. The cells formed solid islands, together with large, pleomorphic, polyhedral or spindlelike atypical cells with hyperchromatic nuclei and osteoblast morphology. Indifferentiated sarcoma and osteosarcoma areas were noted next to CRCC areas (Figure 4A,B; 5A,B). Immunohistochemical evaluation revealed that carcinoma areas had a profile that supported CRCC by staining positively with cytokeratin (CK) 8-18, CK7, and EMA, and negatively with CD10 and vimentin. Sarcoma areas stained focally with $\mathrm{CK}$ and diffusely with vimentin while there was no staining with CD34, S-100, Actin, and HHF-35 (Figure 6A,B). The diagnosis was therefore 'sarcomatoid CRCC with osteosarcomatous differentiation'. Chemotherapy was planned but the patient died due to surgical complications before treatment was started.

\section{DISCUSSION}

Chromophobe RCC are a rare RCC subtype that have the third highest incidence after conventional and papillary RCC (2,3). Histologically, CRCC cases have a typical appearance consisting of polygonal cells with a perinuclear clear halo, pale or eosinophilic cytoplasm and prominent cytoplasmic borders (1,2). Immunohistochemically, CRCC's stain positively with CD117, CK7, CK14, and EMA and negatively with high molecular weight cytokeratin, CK20, vimentin and CD10. Conventional RCC's show negative immunohistochemical staining with $\mathrm{CK} 7$ and positive staining with CD10 and vimentin (2). Our CRCC case stained positively with CK 7, EMA and low molecular weight cytokeratin (CK8-18) and negatively with vimentin and CD10. The spindle cells in the sarcomatoid areas have a nonspecific immunohistochemical profile. There may be reactivity with $\mathrm{CK}$ and vimentin, similar to sarcomatoid carcinomas seen in other areas (7).

RCC with sarcomatoid differentiation is not a separate histological entity and it just signifies the differentiation of the epithelial component that may be present in all RCC subtypes to a higher grade tumor resembling a sarcoma characterized by spindle cells with atypical cytological features $(1,6,9)$.

Sarcomatoid differentiation is seen most commonly in CRCC among the RCC subtypes at a rate of $9 \%(2,9)$. Peralta-Venturina et al. have studied 100 kidney tumors and found the rates for sarcomatoid differentiation to be $8 \%$ in conventional RCC, $9 \%$ in chromophobe RCC, $3 \%$ in papillary RCC, $29 \%$ in collecting duct carcinoma and $11 \%$ in unclassified RCC (8). The sarcoma component usually consists of areas of malignant fibrous histiocytoma, fibrosarcoma and undifferentiated sarcoma (5). Less than 10 cases have been reported with a heterologous element such as chondrosarcoma, osteosarcoma or rhabdomyosarcoma (7). There are 3 case reports in the English literature of CRCC cases containing osteosarcoma-like areas $(1,5,9)$ and two of these tumors had a retroperitoneal mass as in our case $(5,9)$. The tumor protruded from the lower half of the kidney, causing abdominal spread and pulmonary $(5,9)$ and hepatic (5) metastases in both cases, leading to death due to widespread disease. The other case was limited to the kidney but had invaded the perirenal fatty tissue and renal vein. Hepatic, pulmonary and bone metastases developed three months after the surgery, necessitating radiotherapy and chemotherapy (1). Itoh et al. (5) have interpreted the positive staining with CK and EMA in the sarcoma areas in their own case and other sarcomatoid RCC cases reported in 


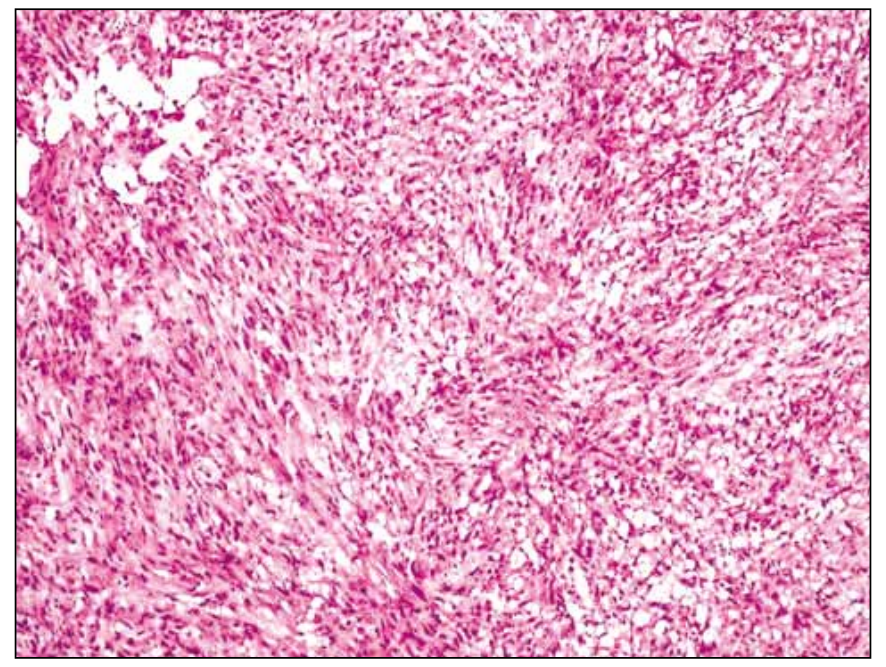

Figure 2: Atypical spindle-type cells making up long fascicles on frozen section.

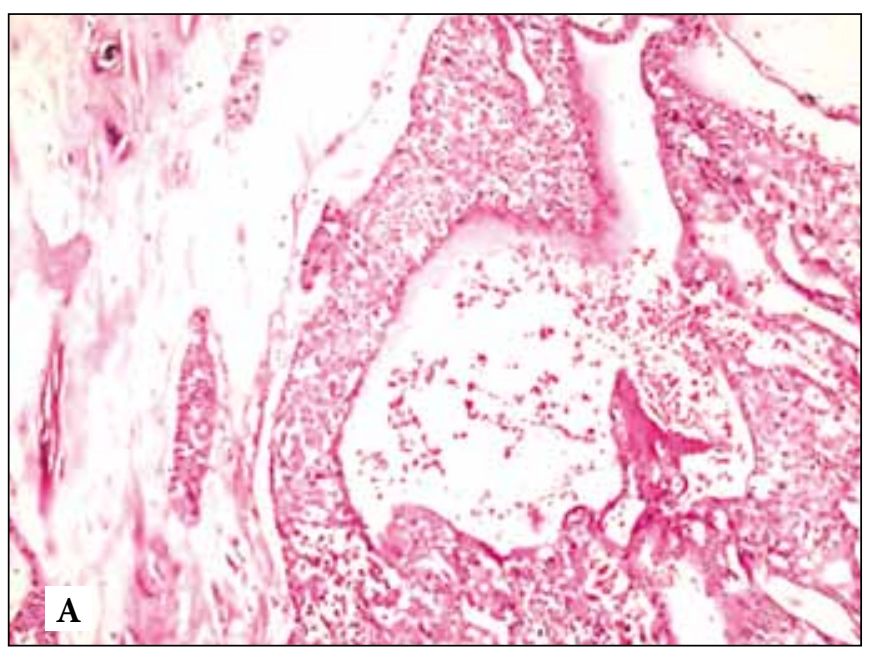

Figure 4A,B: Chromophobe renal cell carcinoma areas.

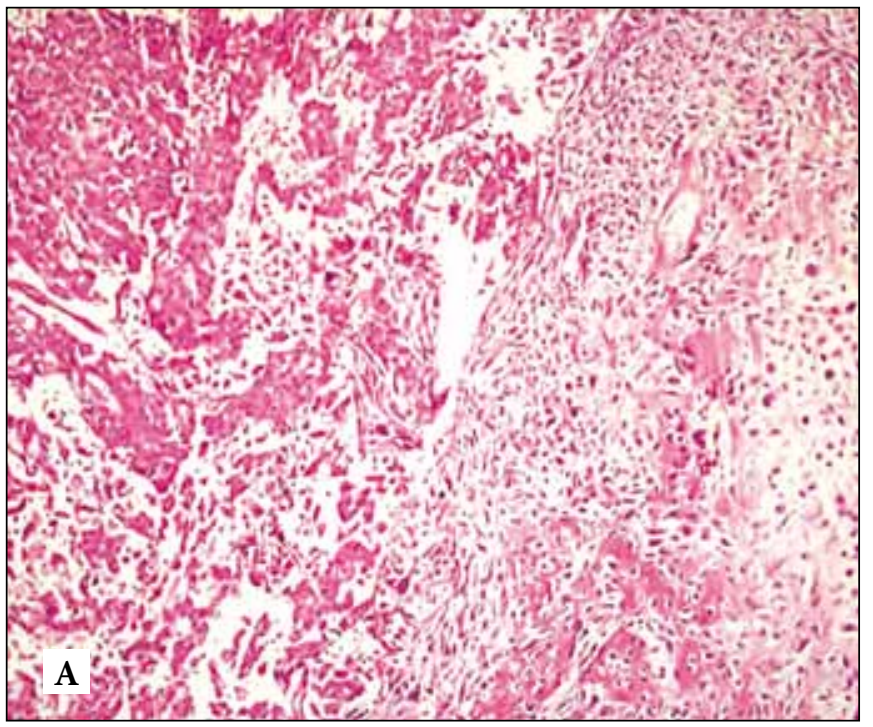

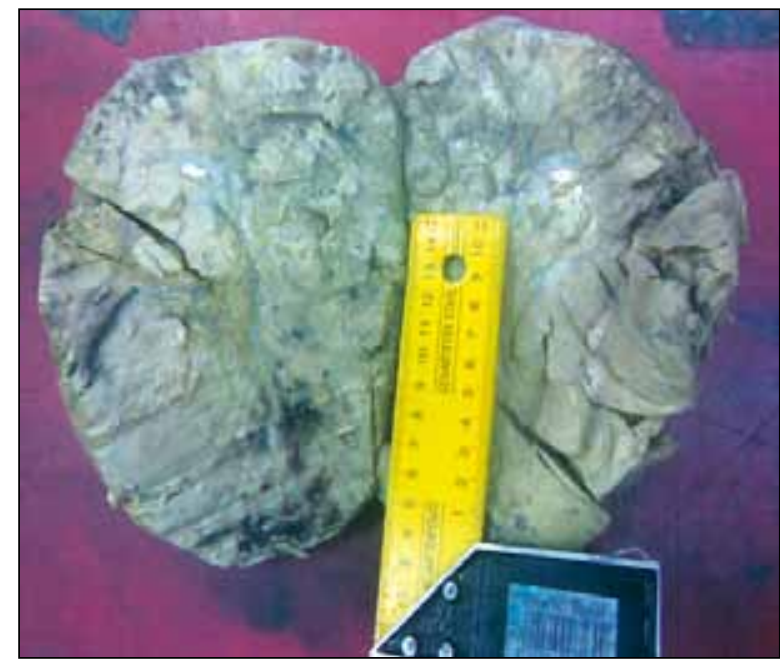

Figure 3: Macroscopic examination reveals a solid cream-brown tumoral mass $18 \times 18 \times 11 \mathrm{~cm}$ in size with widespread necrotic areas and some solid foci.
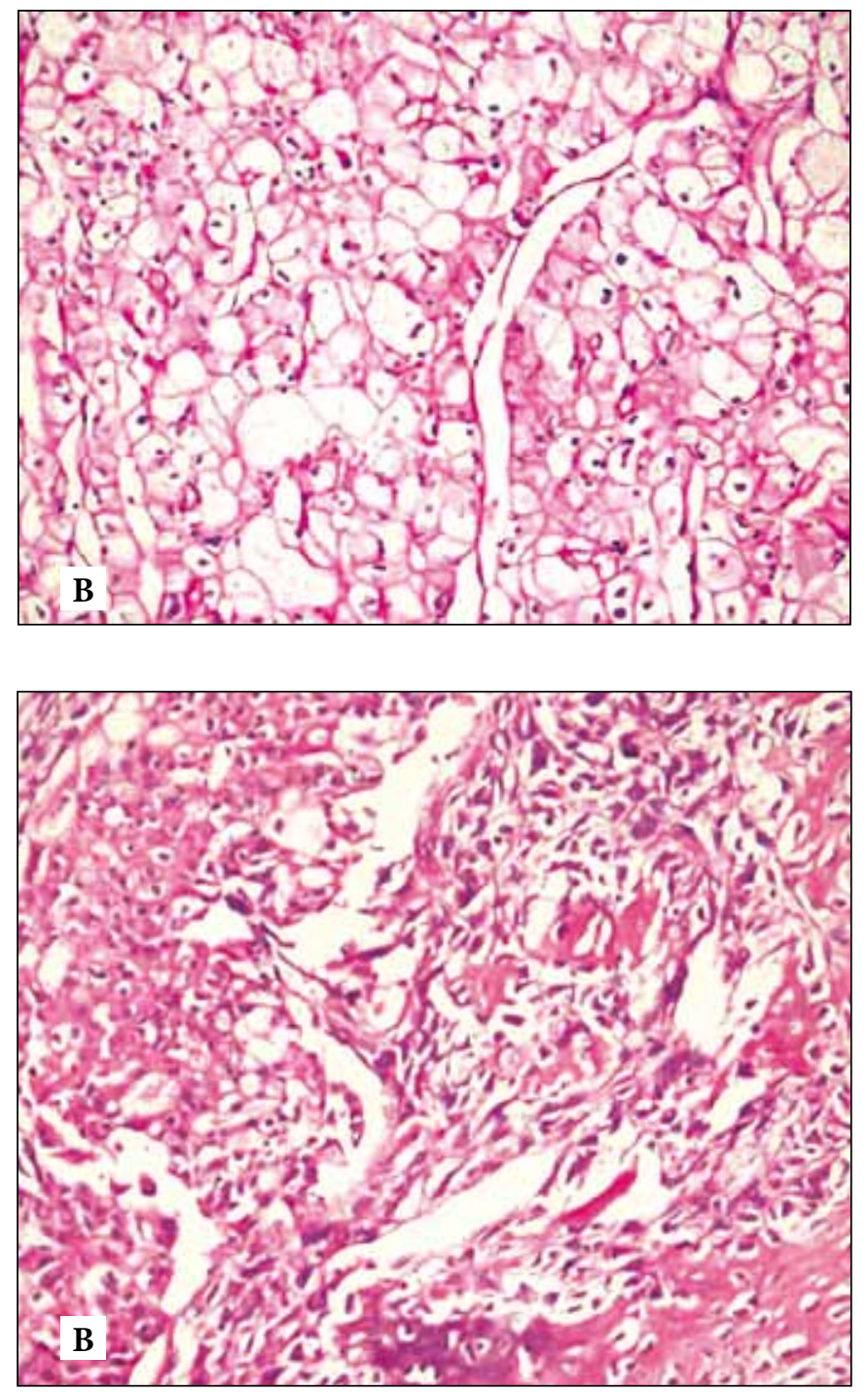

Figure 5A,B: Transition areas from chromophobe renal cell carcinoma to osteosarcoma. 

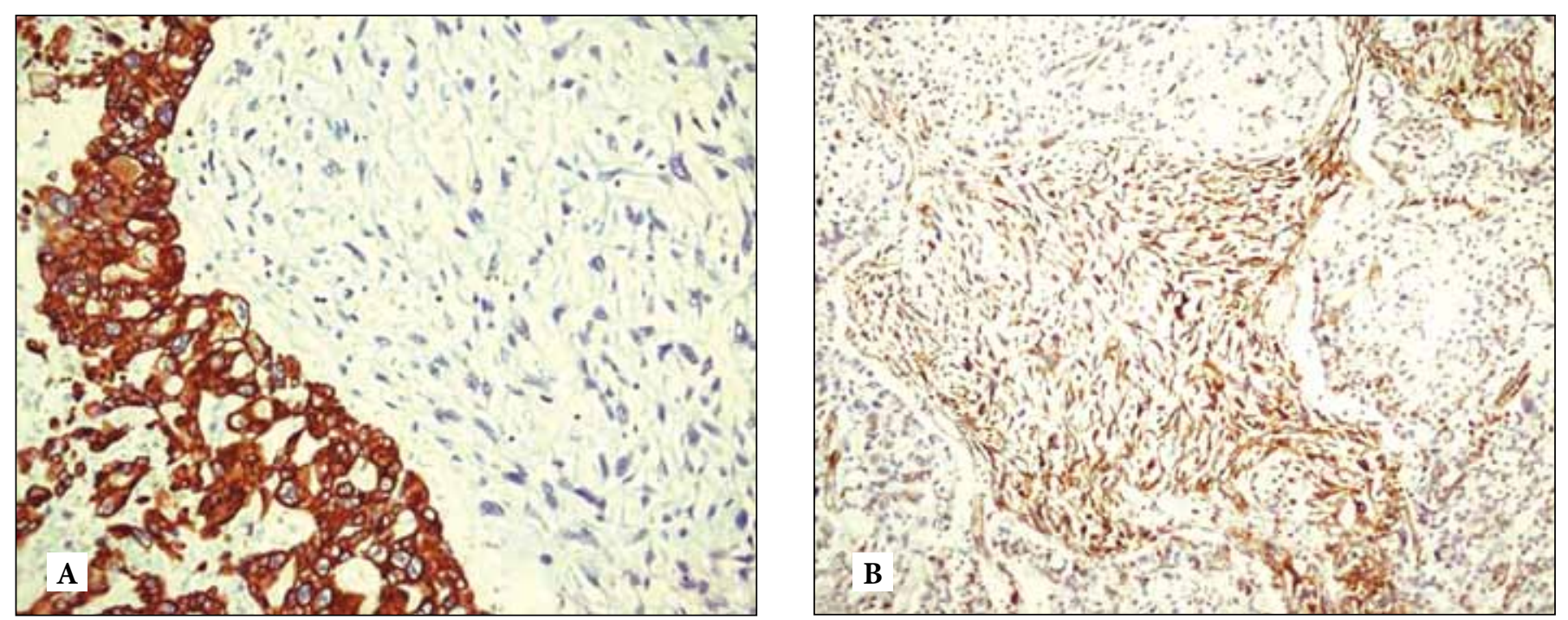

Figure 6: A) Positive staining with cytokeratin 8-18 in chromophobe renal cell carcinoma but no immune staining in sarcoma areas, B) Positive staining with vimentin in sarcoma areas but no immune staining in chromophobe renal cell carcinoma areas.

the literature $(7,10)$ as being due to a metaplastic change of the osteosarcoma-like component that can morphologically mimic osteosarcoma. Immunohistochemical analysis of our case also revealed diffuse staining with vimentin and positive staining of a few cells with cytokeratin in the sarcoma areas.

The presence of a sarcomatoid component has been reported to be associated with an increased risk of metastasis and an unfavorable prognosis (3,7-9). The CRCC cases with sarcomatoid differentiation in the literature have shown distant organ metastases such as to the bone, liver, lung and lymph nodes (10).

Nagashima et al. have published a CRCC case with sarcomatoid differentiation who died due to systemic metastases 14 months after the diagnosis and histopathological investigation of the metastatic foci showed a tumor with a sarcomatoid appearance that did not contain an epithelial element (11).

Quiroga-Garza et al. have published a CRCC cases with sarcomatoid differentiation while a metastatic periaortic lymph node similarly revealed tumor with a sarcomatoid appearance (1). These results support the presence of a tumor progression pathway from chromophobe to sarcomatoid RCC. Careful postoperative follow-up for potential histological progression of CRCC to the sarcomatoid subtype has been suggested (11). Klatte et al. have reported that a sarcomatoid component accompanies $50 \%$ of metastatic CRCC cases, that these cases have a tendency to have hepatic metastases, unresponsiveness to immunotherapy and that the prognosis is unfavorable (6).
The tumor in the form of a retroperitoneal mass in our case was almost totally excised and the left kidney left alone as the MR images and the peroperative findings did not provide a clear picture and the tumor's frozen section report was malignant mesenchymal tumor. No non-tumoral kidney tissue was observed in the macroscopic and microscopic investigation of the tumor.

In conclusion, CRCC with osteosarcomatous differentiation is a very rare tumor and can be encountered as a retroperitoneal mass with a rapid and progressive course. RCC with sarcomatoid differentiation should therefore always be considered for retroperitoneal tumors that look like mesenchymal tissue on histology and the medical and surgical treatment of the patient should be planned taking this possibility into account.

\section{REFERENCES}

1. Quiroga-Garza G, Khurana $H$, Shen S, Ayala AG, Ro JY: Sarcomatoid chromophobe renal cell carcinoma with heterologous sarcomatoid elements. A case report and review of the literature. Arch Pathol Lab Med 2009, 133:1857-1860

2. Murphy WM, Grignon DJ, Perlman EJ: Kidney Tumors in Adults. In Silverberg SG, Sobin LH (eds). Tumors of the Kidney, Bladder and Related Urinary Structures. AFIP Atlas of Tumor Pathology. 4th series, Fascicle 1. Washington DC, American Registry of Pathology, 2004, 101-240

3. Amin MB, Paner GP, Alvarado-Cabrero I, Young AN, Stricker HJ, Lyles RH, Moch H: Chromophobe renal cell carcinoma: histomorphologic characteristics and evaluation of conventional pathologic prognostic parameters in 145 cases. Am J Surg Pathol 2008, 32:1822-1834 
4. Cheville JC, Lohse CM, Zincke H, Weaver AL, Leibovich BC, Frank I, Blute ML: Sarcomatoid renal cell carcinoma: an examination of underlying histologic subtype and an analysis of associations with patient outcome. Am J Surg Pathol 2004, 28:435-441

5. Itoh T, Chikai K, Ota S, Nakagawa T, Takiyama A, Mouri G, Shinohara N, Yamashita T, Suzuki S, Koyanagi T, Nagashima K: Chromophobe renal cell carcinoma with osteosarcoma-like differentiation. Am J Surg Pathol 2002, 26:1358-1362

6. Klatte T, Han KR, Said JW, Böhm M, Allhoff EP, Kabbinavar FF, Belldegrun AS, Pantuck AJ: Pathobiology and prognosis of chromophobe renal cell carcinoma. Urol Oncol 2008, 26:604-609

7. Viswanathan S, Desai SB, Prabhu SR, Amin MB: Squamous differentiation in a sarcomatoid chromophobe renal cell carcinoma: an unusual case report with review of the literature. Arch Pathol Lab Med 2008, 132:1672-1674
8. De Peralta-Venturina M, Moch H, Amin M, Tamboli P, Hailemariam S, Mihatsch M, Javidan J, Stricker H, Ro JY, Amin MB: Sarcomatoid differentiation in renal cell carcinoma: a study of 101 cases. Am J Surg Pathol 2001, 25:275-284

9. Gira FA, Barbieri A, Fellegara G, Zompatori M, Corradi D: Dedifferentiated chromophobe renal cell carcinoma with massive osteosarcoma-like divergent differentiation: a singular entity in the spectrum of retroperitoneal calcifying tumors. Int J Surg Pathol 2010, 18:419-423

10. Cserni G, Kovács BR, Tarján M, Sápi Z, Domján Z, Szabó Z: Sarcomatoid renal cell carcinoma with foci of chromophobe carcinoma. Pathol Oncol Res 2002, 8:142-144

11. Nagashima Y, Okudela K, Osawa A, Nakamura N, Kawasaki C, Moriyama M, Nakamura N, Nakatani Y, Kitamura H, Aoki I: Chromophobe renal cell carcinoma with sarcomatoid change. A case report. Pathol Res Pract 2000, 196:647-651 